\title{
Differential effects of vilazodone versus citalopram and paroxetine on sexual behaviors and serotonin transporter and receptors in male rats
}

\author{
Ronald S. Oosting ${ }^{1} \cdot$ Johnny S. Chan $^{1} \cdot$ Berend Olivier $^{1,2}$ - Pradeep Banerjee ${ }^{3}$. \\ Yong Kee Choi ${ }^{4} \cdot$ Frank Tarazi $^{4}$
}

Received: 24 June 2015 / Accepted: 4 December 2015 / Published online: 13 January 2016

(C) The Author(s) 2016. This article is published with open access at Springerlink.com

\begin{abstract}
Rationale Sexual side effects are commonly associated with selective serotonin reuptake inhibitor (SSRI) treatment. Some evidence suggest that activation of $5-\mathrm{HT}_{1 \mathrm{~A}}$ receptors attenuates SSRI-induced sexual dysfunction.

Objective This study in male rats compared the effects of vilazodone, an antidepressant with SSRI and $5-\mathrm{HT}_{1 \mathrm{~A}}$ receptor partial agonist activity, with other prototypical SSRIs (citalopram and paroxetine) on sexual behaviors and 5-HT receptors (5- $\mathrm{HT}_{1 \mathrm{~A}}$ and $\left.5-\mathrm{HT}_{2 \mathrm{~A}}\right)$ and transporter $\left(5-\mathrm{HT}_{\mathrm{T}}\right)$ levels in select forebrain regions of the limbic system using quantitative autoradiography. Methods Rats received vilazodone (1, 3, and $10 \mathrm{mg} / \mathrm{kg}$ ), citalopram $(10$ and $30 \mathrm{mg} / \mathrm{kg})$, or paroxetine $(10 \mathrm{mg} / \mathrm{kg})$ treatment for 14 days. Sexual behaviors (frequency and latency of mounts, intromissions, and ejaculations) were measured in the presence of an estrous female rat on days 1 (acute), 7 (subchronic), and 14 (chronic).

Results Vilazodone-treated rats exhibited no sexual dysfunction compared with controls; in contrast, the citalopram- and paroxetine-treated rats exhibited impaired copulatory and ejaculatory behaviors after subchronic and chronic treatments. Chronic vilazodone treatment markedly decreased $5-\mathrm{HT}_{1 \mathrm{~A}}$
\end{abstract}

Ronald S. Oosting

R.S.Oosting@uu.nl

1 Division of Pharmacology, Utrecht Institute for Pharmaceutical Sciences, Utrecht University, Universiteitsweg 99, 3584 CG Utrecht, The Netherlands

2 Department of Psychiatry, Yale University School of Medicine, New Haven, CT, USA

3 Forest Research Institute, Jersey City, NJ, USA

4 Department of Psychiatry and Neuroscience Harvard Medical School and McLean Hospital, Belmont, MA, USA receptor levels in cortical and hippocampal regions, while the SSRIs increased levels of this receptor in similar regions. All chronic treatments reduced $5-\mathrm{HT}_{\mathrm{T}}$ levels across the forebrain; however, the magnitude of the decrease was considerably smaller for vilazodone than for the SSRIs.

Conclusions The current studies showed that chronic treatment with vilazodone, in contrast to citalopram and paroxetine, was not associated with diminished sexual behaviors in male rats, which may be related to the differential effects of vilazodone on $5-\mathrm{HT}_{1 \mathrm{~A}}$ receptor and $5-\mathrm{HT}_{\mathrm{T}}$ levels relative to conventional SSRIs.

Keywords Sexual behavior $\cdot 5-\mathrm{HT}_{1 \mathrm{~A}} \cdot 5-\mathrm{HT}_{2 \mathrm{~A}} \cdot 5-\mathrm{HT}_{\mathrm{T}}$. 5-HT · Vilazodone $\cdot$ Paroxetine $\cdot$ Citalopram $\cdot$ Ejaculatory behavior $\cdot$ SSRI

\section{Introduction}

Major depressive disorder (MDD) is one of the most common mental disorders, with an estimated lifetime prevalence in the USA of $19.2 \%$ (Kessler et al. 2010). Selective serotonin reuptake inhibitors (SSRIs) are efficacious in treating MDD and are the most commonly prescribed first-line therapy. However, their clinical effectiveness is often limited by poor adherence and discontinuation due to lack of therapeutic response and adverse effects (Nantz et al. 2009). Sexual dysfunction, which affects up to $60 \%$ of patients treated with SSRIs (Kennedy and Rizvi 2009), is a leading cause of treatment nonadherence (Ashton et al. 2005) and is reported by patients to be one of the most unacceptable side effects associated with SSRIs (Hu et al. 2004). Therefore, reducing the incidence and burden of sexual dysfunction associated with SSRIs is important in improving clinical outcomes in patients with MDD. 
Approaches to mitigating the sexual dysfunction associated with SSRI treatment include lowering dosage, switching antidepressant medications, or adding concomitant medications such as a phosphodiesterase inhibitor type 5 (PDE5; e.g., sildenafil), a norepinephrinedopamine reuptake inhibitor (e.g., bupropion), or a 5$\mathrm{HT}_{1 \mathrm{~A}}$ receptor partial agonist (e.g., buspirone) (Rizvi and Kennedy 2013). Clinical and preclinical evidence supports a role for the 5- $\mathrm{HT}_{1 \mathrm{~A}}$ receptor in regulating sexual behavior. Buspirone was shown to improve sexual function in depressed patients that were experiencing sexual dysfunction while taking the SSRIs paroxetine and citalopram (Landen et al. 1999). In male rats, buspirone and full $5-\mathrm{HT}_{1 \mathrm{~A}}$ receptor agonists (8-OH-DPAT and flesinoxan) promoted sexual behavior by decreasing ejaculation latencies (Chan et al. 2010; Snoeren et al. 2014). In contrast, the 5- $\mathrm{HT}_{1 \mathrm{~A}}$ receptor antagonist WAY-100635 inhibited sexual behavior when it was coadministered with citalopram (de Jong et al. 2005a) or paroxetine (Looney et al. 2005) and when administered in 5-HT knockout rats (Chan et al. 2011). These studies suggest that $5-\mathrm{HT}_{1 \mathrm{~A}}$ receptor antagonism only inhibits sexual behaviors under conditions of chronically elevated serotonin (5-HT) (Olivier et al. 2011).

Vilazodone is an SSRI and 5-HT $1 \mathrm{~A}$ receptor partial agonist (Dawson and Watson 2009) approved by the Food and Drug Administration (FDA) for the treatment of MDD in adults (Forest 2011). Efficacy for vilazodone in adults with MDD was demonstrated in two pivotal trials (Khan et al. 2011; Rickels et al. 2009); safety was further supported in a 52-week open-label study (Robinson et al. 2011). Vilazodone treatment was associated with relatively low adverse impact on sexual function relative to the high prevalence of sexual dysfunction in patients at baseline (Clayton et al. 2013). Limited evidence from these clinical trials in MDD has shown that the incidence of sexual dysfunction was similar between patients treated with vilazodone and patients treated with placebo, suggesting that vilazodone may be associated with less sexual dysfunction than other SSRIs (Clayton et al. 2013).

The mechanism by which $5-\mathrm{HT}_{1 \mathrm{~A}}$ receptor agonists affect sexual behavior is not well understood. Previous evidence showing that $5-\mathrm{HT}_{1 \mathrm{~A}}$ receptor agonists can stimulate male sexual function (Blier and Ward 2003; Chan et al. 2010; Snoeren et al. 2014) suggests that the clinical advantages of vilazodone may in part be mediated through its activity at the $5-\mathrm{HT}_{1 \mathrm{~A}}$ receptor. This study compared the effects of vilazodone treatment and other SSRIs on copulatory and ejaculatory behaviors, as well as on brain 5-HT receptor and transporter levels in select forebrain regions of the limbic system in male rats.

\section{Materials and methods}

\section{Animals}

Male and female Wistar rats (Charles River Laboratories, Germany), initially weighing 250-300 g, were group housed (4 per cage) and maintained under reversed 12/12 h day/night cycles (lights off 7:00 a.m.; lights on 7:00 p.m.); food and water were available ad libitum. Estrus was induced in female rats by a single injection of $50 \mu \mathrm{g}$ estradiol benzoate dissolved in sesame oil 36 to $42 \mathrm{~h}$ before testing with a male rat. Animals were weighed on days 1, 7, and 14 of the drug experiment. All behavioral experiments, including the drug administrations, were reviewed and approved by Utrecht University's animal welfare committee (DEC).

\section{Drugs}

Vilazodone hydrochloride $(1,3,10 \mathrm{mg} / \mathrm{kg})$ and citalopram hydrochloride $(10,30 \mathrm{mg} / \mathrm{kg})$ were received from Forest Laboratories, LLC. Paroxetine $(10 \mathrm{mg} / \mathrm{kg})$ was obtained from a local pharmacy (20 mg tablet, Hexal Pharma Nederland BV) and crushed into powder form. All drugs were dissolved or suspended in vehicle (1\% methylcellulose and water) and were administered orally (PO) at a dose volume of $2 \mathrm{~mL} / \mathrm{kg}$.

\section{Sexual behavior test}

The sexual behavior test was performed as previously described (Chan et al. 2010). Briefly, estrus was induced in female rats with estradiol injection 36 to $42 \mathrm{~h}$ before testing. Male rats were placed in an observation cage $(30 \times 40 \times 60 \mathrm{~cm})$ for a 30 min habituation period. Following the habituation period, an estrous female was placed in the cage and video recording commenced for $30 \mathrm{~min}$. The frequencies of mounts (no vaginal penetration), intromissions (vaginal penetration), and ejaculations, and the latency to the first ejaculation (time between first mount to ejaculation) were measured and scored during the 30min test using Observer ${ }^{\circledR} 5.0$ (Noldus, Wageningen, The Netherlands). Copulatory efficiency was defined as [number of intromissions / (number of intromissions + number of mounts) $] \times 100 \%$. Data from the first ejaculation series, which included all events occurring before the first ejaculation, were reported for mounting frequency, ejaculation latency, and copulatory efficiency. The ejaculation frequency for the entire 30min test was reported. All assessments were performed in the dark phase of the light/dark cycle under dim red light conditions.

\section{Sexual training and the selection of male rats}

In order to achieve stable sexual behavior, male rats $(N=145)$ were trained once per week for five consecutive weeks 
(pretreatment) against an estrous female in an observation cage. Male rats that exhibited an ejaculation frequency of $2-$ 3 per 30-min test in the final two of the five training sessions were classified as normal-performers (Pattij et al. 2005) and were included in the drug studies $(n=98)$.

\section{Experimental design}

\section{Sexual behavior test}

Normal-performing male rats were randomly divided into seven treatment groups ( $n=14 /$ group): vehicle, vilazodone $1 \mathrm{mg} /$ $\mathrm{kg}$, vilazodone $3 \mathrm{mg} / \mathrm{kg}$, vilazodone $10 \mathrm{mg} / \mathrm{kg}$, citalopram $10 \mathrm{mg} / \mathrm{kg}$, citalopram $30 \mathrm{mg} / \mathrm{kg}$, and paroxetine $10 \mathrm{mg} / \mathrm{kg}$. All treatments were administered once daily for 14 days, either $1 \mathrm{~h}$ before the sexual test or around 11:00 a.m. on days without a sex test. The evaluations of sexual behaviors were performed on day 1 (acute), day 7 (subchronic), and day 14 (chronic).

\section{Animal treatment and tissue preparation}

Following the chronic (14 days) treatment with vilazodone (3, $10 \mathrm{mg} / \mathrm{kg})$, citalopram $(10 \mathrm{mg} / \mathrm{kg})$, paroxetine $(10 \mathrm{mg} / \mathrm{kg})$, or vehicle ( $1 \%$ methylcellulose and water) and the day 14 sexual behavior tests, $n=8$ animals per treatment group were randomly chosen for the autoradiography experiments. Rats were decapitated, and their brains were rapidly excised and stored at $-80^{\circ} \mathrm{C}$. Next, coronal sections $(10 \mu \mathrm{m})$ were cut on a cryostat at $-20^{\circ} \mathrm{C}$ and stored at $-80^{\circ} \mathrm{C}$. Brain tissue from regions that are thought to mediate neural pathways and behaviors (and are typically disturbed in MDD patients) were selected for evaluation (Baldessarini 2006). The following brain regions selected for quantitative autoradiography: medial prefrontal cortex (MPC), dorsolateral frontal cortex (DFC), medial caudate putamen (CP-M), lateral caudate putamen (CP-L), nucleus accumbens (NAc), hippocampus $\mathrm{CA}_{1}$ region (HIPP-CA $\mathrm{C}_{1}$, hippocampus $\mathrm{CA}_{3}$ region (HIPP-CA $\mathrm{CA}_{3}$ ), and entorhinal cortex (EC).

\section{Autoradiography assays}

Serotonin transporter $\left(5-\mathrm{HT}_{\mathrm{T}}\right)$ levels were determined as previously described (Zhang et al. 2002). First, sections were preincubated for $2 \mathrm{~h}$ at $4{ }^{\circ} \mathrm{C}$ in $50 \mathrm{mM}$ Tris- $\mathrm{HCl}$ buffer (pH 7.4) containing $120 \mathrm{mM} \mathrm{NaCl}$. Next, sections were incubated for $24 \mathrm{~h}$ at room temperature (RT) with fresh buffer containing $1 \mathrm{nM}\left[{ }^{3} \mathrm{H}\right]$ cyanoimipramine $\left(5-\mathrm{HT}_{\mathrm{T}}\right.$ ligand) and the nonspecific binding (NSB) agent $5 \mathrm{mM}$ sertraline. Following incubation, sections were washed twice for $30 \mathrm{~min}$ in ice-cold buffer, rinsed in water, and air dried.

$5-\mathrm{HT}_{1 \mathrm{~A}}$ receptor levels were determined as previously described (Tarazi et al. 2002). Sections were preincubated for
$60 \mathrm{~min}$ at RT in $50 \mathrm{mM}$ Tris- $\mathrm{HCl}$ buffer (pH 7.6) containing ascorbic acid $(0.1 \%, w / v), 4 \mathrm{mM} \mathrm{CaCl}_{2}$, and $10 \mu \mathrm{M}$ pargyline-HCl. Next, sections were incubated for $1 \mathrm{~h}$ at RT with fresh buffer containing $2.0 \mathrm{nM}\left[{ }^{3} \mathrm{H}\right] 8-\mathrm{OH}-\mathrm{DPAT}$ and $1 \mu \mathrm{M}$ 5-HT as the NSB agent. Following incubation, sections were washed twice for $5 \mathrm{~min}$ in ice-cold buffer, rinsed in water, and air dried.

$5-\mathrm{HT}_{2 \mathrm{~A}}$ receptor levels were determined as previously described (Tarazi et al. 2002). Sections were preincubated for $1 \mathrm{~h}$ at RT in $50 \mathrm{mM}$ Tris-HCl buffer ( $\mathrm{pH}$ 7.7). Next, sections were incubated for $1 \mathrm{~h}$ at RT in fresh buffer containing $3.0 \mathrm{nM}$ $\left[{ }^{3} \mathrm{H}\right]$ ketanserin, $1 \mu \mathrm{M}$ prazosin, and $100 \mathrm{nM}$ tetrabenzine with the NSB $1 \mu \mathrm{M}$ methysergide. Following the incubation, sections were washed twice for $30 \mathrm{~min}$ in ice-cold buffer, rinsed in water, and air-dried.

For image analysis, radiolabeled slides and calibrated $\left[{ }^{3} \mathrm{H}\right]$ standards (Amersham) were exposed to Biomax MR films for 5-6 weeks at $4{ }^{\circ} \mathrm{C}$. The films were developed and fixed in Kodak D-19 for 5 min at RT. Optical density (OD) in brain regions of interest was measured with a computerized densitometric image analyzer (MCID-4 system, Imaging Research; St. Catharines, Ontario). OD was converted to $\mathrm{nCi} / \mathrm{mg}$ of tissue with calibrated $\left[{ }^{3} \mathrm{H}\right]$ standards. After subtracting nonspecific binding from total binding, the specific binding was determined and expressed as femtomole bound per milligram tissue.

\section{Statistical analysis}

All behavioral data were analyzed by analysis of variance (ANOVA; SPSSv22.0) to test for overall significance. If overall significant effects were found, post hoc Dunnett $t$ tests were used to evaluate differences between active- and vehicletreatment groups on the same experimental day. Data from the autoradiography assays were analyzed using a two-way ANOVA to evaluate changes across treatments and brain regions for each assay. In case of overall statistically significant effects for drug or brain region, post hoc Dunnett $t$ tests were used to evaluate differences between treatment and vehicle groups. All significance testing was two-sided at the $P<.05$ level. All values are shown as the mean and standard error of the mean (SEM).

\section{Results}

\section{Sexual behavior tests}

\section{Day 1/acute administration}

On day 1, the vehicle-treated rats displayed an average of 2.5 ejaculations. Following acute administrations of vilazodone, citalopram, and paroxetine, there were no significant effects of 
treatment on any of the sexual behavior parameters (Figs. 1 and $2 \mathrm{a}-\mathrm{b})$

\section{Day $7 /$ subchronic administration}

There were no differences in vehicle-treated rats on day 7 compared with day 1 , indicating stable endophenotypes of the sexual behavior parameters.

For the day 7 tests, there were significant effects of treatment on mount frequency $\left(F_{6,91}=5.52 ; P<.001\right)$, copulatory efficiency $\left(F_{6,91}=5.61 ; P<.001\right)$, latency to first ejaculation $\left(F_{6,91}=12.65 ; P<.001\right)$, and ejaculation frequency $\left(F_{6}\right.$, $\left.{ }_{91}=3.94 ; P=.002\right)$. Post hoc comparisons showed that vilazodone-treated rats did not display any significant differences from vehicle-treated rats in sexual behavior after 7 days of treatment. In contrast, citalopram-treated rats displayed increased latency to ejaculation and decreased ejaculation frequency compared with vehicle-treated controls $(P<.05)$ (Fig. 2a-b). Paroxetine-treated rats displayed significantly impaired sexual behavior on all measures after 7 days of treatment $(P<.05)$ (Figs. 1 and 2$)$.

\section{Day 14/chronic administration}

Representative traces of individual rat scores for mounts, intromissions, and ejaculations during the 30-min sex test on day 14 (i.e., chronic treatment) are shown in Fig. 3.

On day 14 , there were significant effects of treatment for mount frequency $\left(F_{6,91}=3.59 ; P=.003\right)$, copulatory efficiency $\left(F_{6,91}=3.83 ; P=.002\right)$, latency to first ejaculation $\left(F_{6}\right.$, $\left.{ }_{91}=4.10 ; P=.001\right)$, and ejaculation frequency $\left(F_{6,91}=5.88\right.$; $P<.001)$. Similar to the previous test days, vilazodone-treated rats did not display any differences in the sexual behaviors compared with vehicle-treated rats. In contrast, citalopramtreated rats had an increase in mount frequency $(P<.05$; $10 \mathrm{mg} / \mathrm{kg}$ ) yet decreased ejaculation frequency and copulatory efficiency $(P<.05 ; 10$ and $30 \mathrm{mg} / \mathrm{kg})$ (Figs. 1 and $2 \mathrm{~b}$ ). Paroxetine-treated rats displayed no differences in mount frequency and ejaculation latency compared to vehicle-treated rats; however, ejaculation frequency and copulatory efficiency were decreased $(P<.05)$ (Figs. 1 and 2$)$.

During the day 14 sex test, the number of rats exhibiting 1 , 2, 3, or 4 ejaculations was comparable following chronic

\section{Vilazodone}

\section{a Mount Frequency}

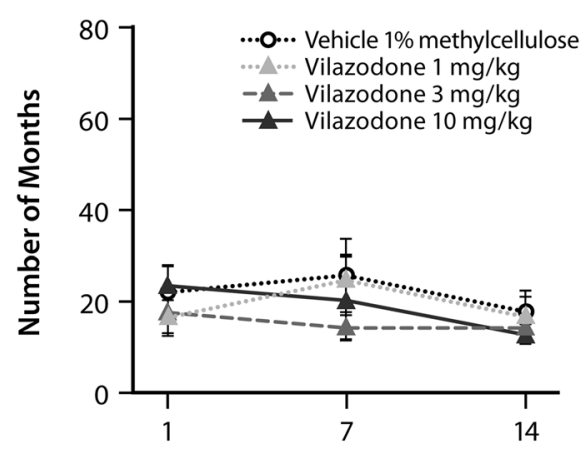

\section{b Copulatory Efficiency}

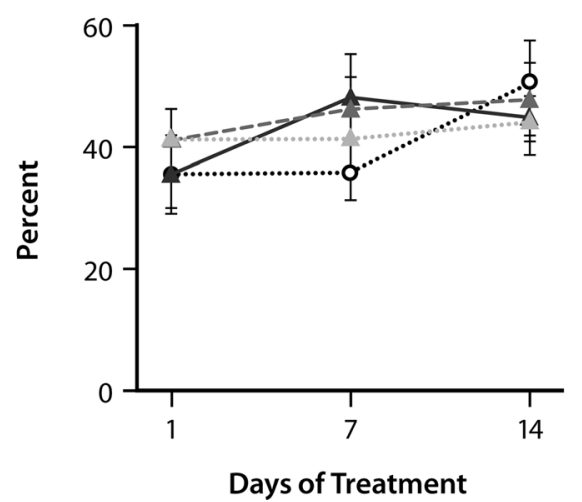

Fig. 1 Effects of vilazodone, citalopram, and paroxetine on first series copulatory behavior in male rats. Effects of vilazodone (1, 3, and $10 \mathrm{mg}$ / $\mathrm{kg})$, citalopram ( 10 and $30 \mathrm{mg} / \mathrm{kg})$, and paroxetine $(10 \mathrm{mg} / \mathrm{kg})$ on a mount frequency and $\mathbf{b}$ copulatory efficiency (defined as number of intromissions / [number of intromissions + number of mounts] $) \times 100 \%$
Citalopram
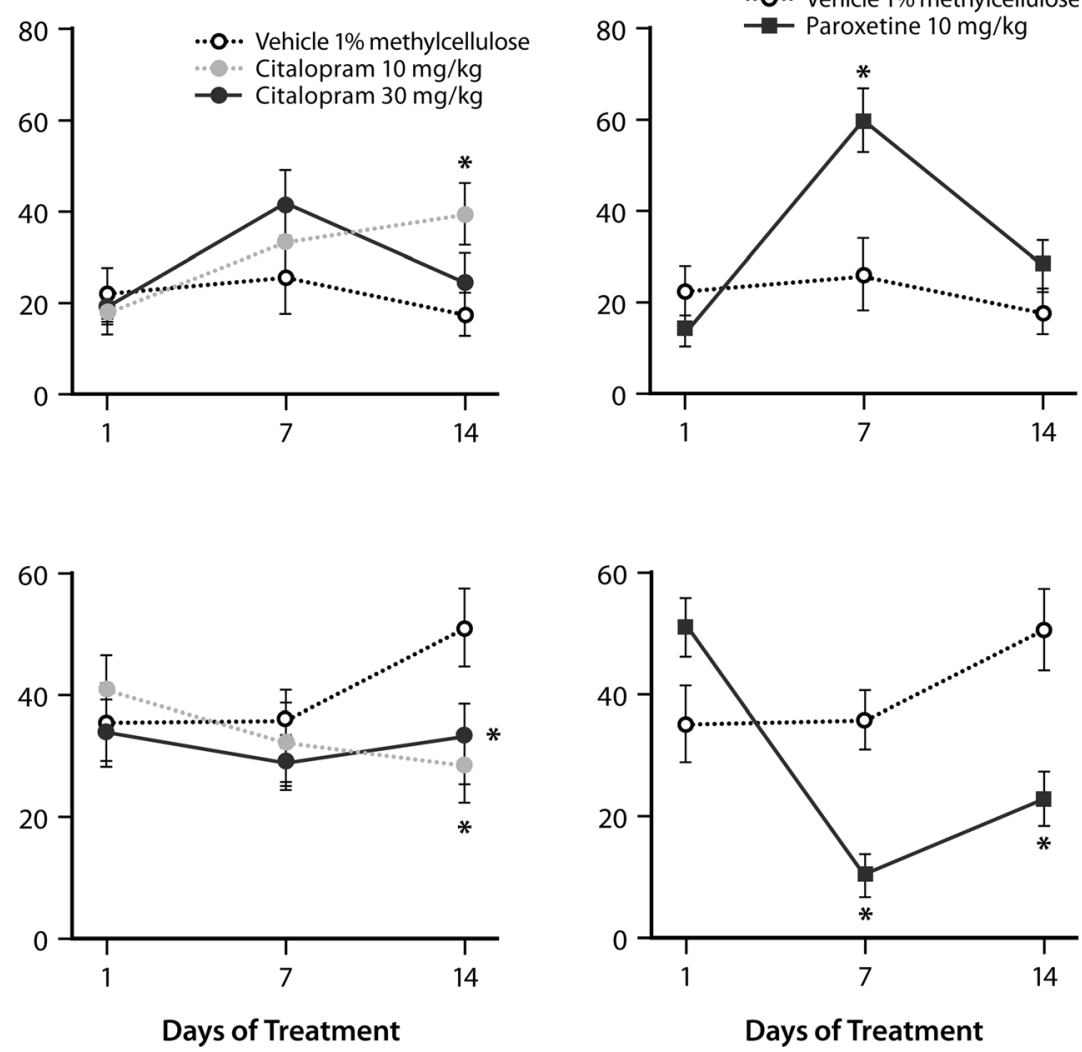

during the first ejaculatory series of the 30 -min sex conducted after treatment on day 1 (acute), day 7 (subchronic), and day 14 (chronic) in male Wistar rats $(n=14 / \mathrm{drug} / \mathrm{dose})$. Data are shown as the mean $\pm \mathrm{SEM}$. $* P<.05$ compared with vehicle 
Vilazodone

a 1st Ejaculation Latency

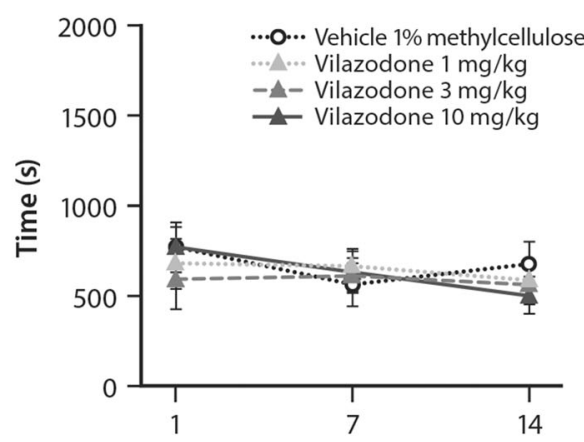

b Ejaculation Frequency

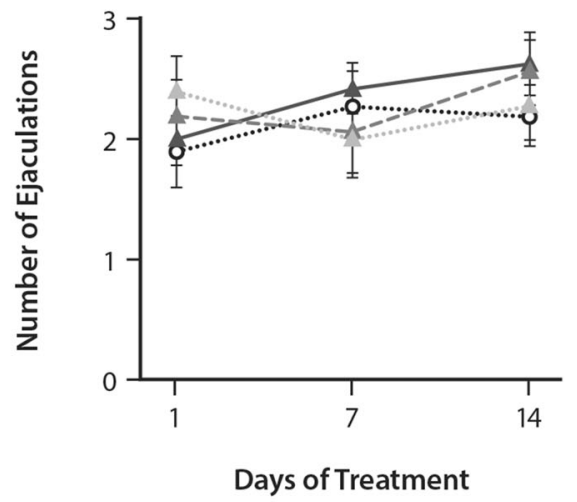

Citalopram
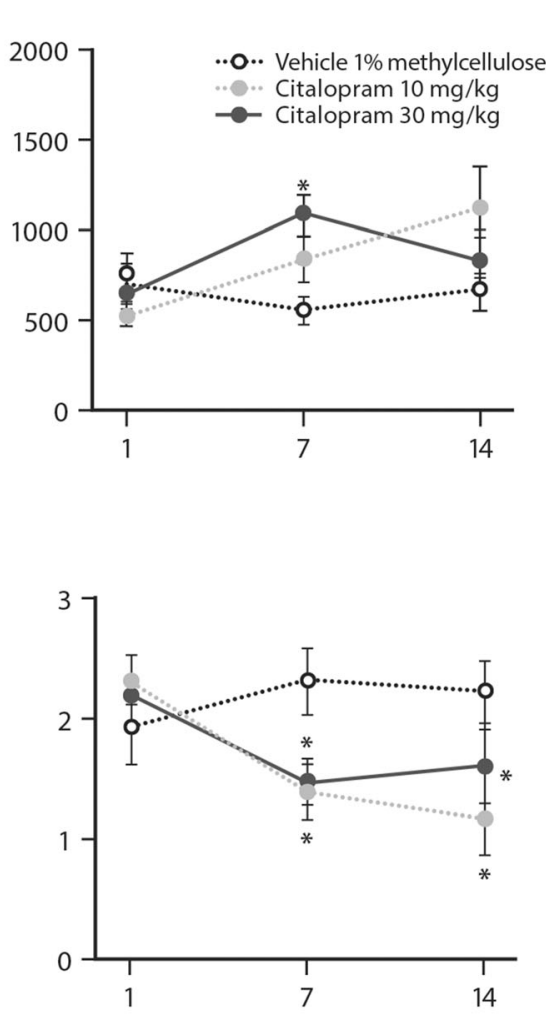

Days of Treatment
Paroxetine

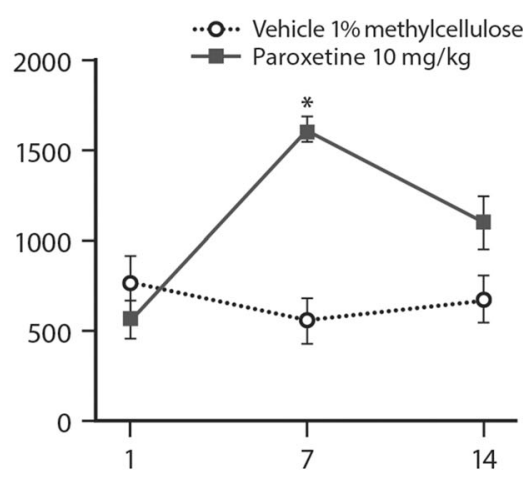

Days of Treatment

\section{c Ejaculation Frequency per Treatment Group on Day 14}

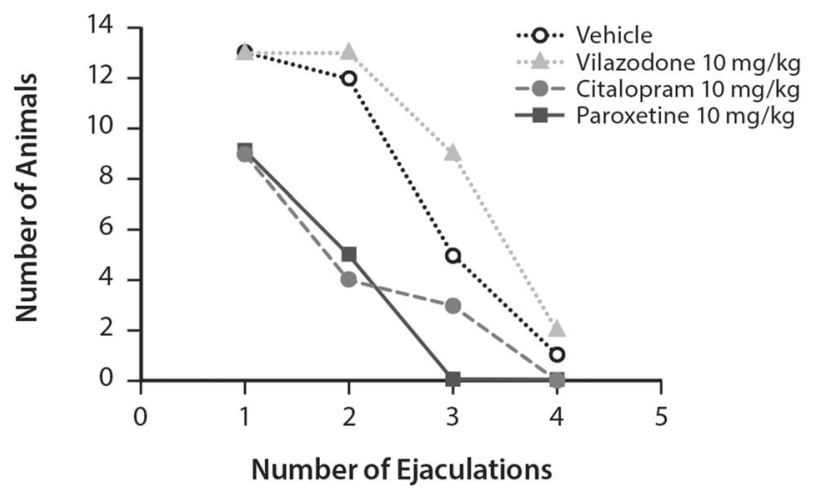

Fig. 2 Effects of vilazodone, citalopram, and paroxetine on ejaculatory behavior in male rats. Effects of vilazodone (1, 3, and $10 \mathrm{mg} / \mathrm{kg}$ ), citalopram $(10$ and $30 \mathrm{mg} / \mathrm{kg})$, and paroxetine $(10 \mathrm{mg} / \mathrm{kg})$ on a first ejaculation latency and $\mathbf{b}$ total ejaculation frequency during the 30-min sex tests conducted after treatment on day 1 (acute), day 7 (subchronic),

treatment with vilazodone $(10 \mathrm{mg} / \mathrm{kg}$; single dose tested) or vehicle, suggesting that chronic vilazodone treatment had no adverse effects on ejaculations. Chronic treatment with citalopram or paroxetine resulted in fewer rats having 1,2 , 3 , or 4 ejaculations during the test than rats treated with vehicle or vilazodone, suggesting that these treatments adversely affected ejaculation frequency (Fig. 2c). and day 14 (chronic) in male Wistar rats ( $n=14 /$ drug/dose). Data are shown as the mean \pm SEM. $* P<.05$ compared with vehicle. $\mathbf{c}$ The number of rats ( $n=14$ /group) that had 1,2,3, or 4 ejaculations during the 30 min sexual behavior test on day 14

\section{$5-\mathrm{HT}_{1 \mathrm{~A}}$ receptor levels}

In vilazodone-treated rats, $5-\mathrm{HT}_{1 \mathrm{~A}}$ receptor levels were reduced in the MPC, HIPP-CA 1 , HIPP-CA 3 , and EC regions $(P<.05)$ (Fig. 4a, Table 1). In contrast, citalopram- and paroxetine-treated rats had increased $5-\mathrm{HT}_{1 \mathrm{~A}}$ receptor levels in the HIPP-CA $A_{1}, \mathrm{HIPP}-\mathrm{CA}_{3}$, and EC regions $(P<.05)$ 


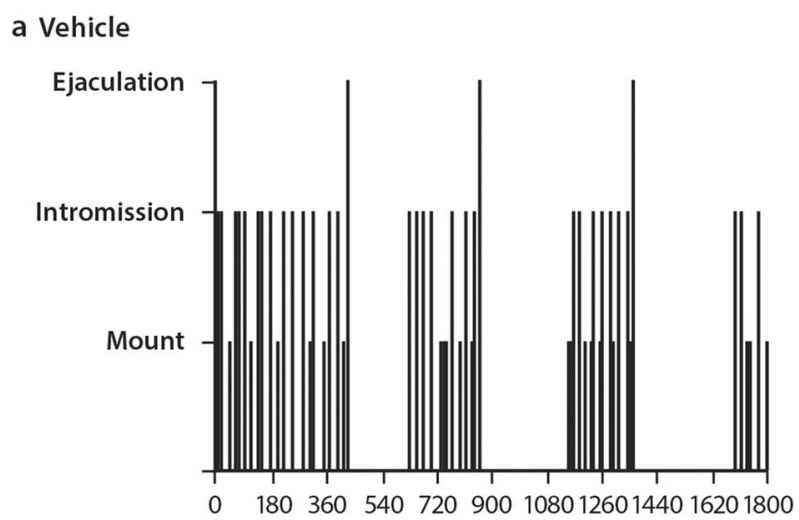

b Vilazodone $(10 \mathrm{mg} / \mathrm{kg})$

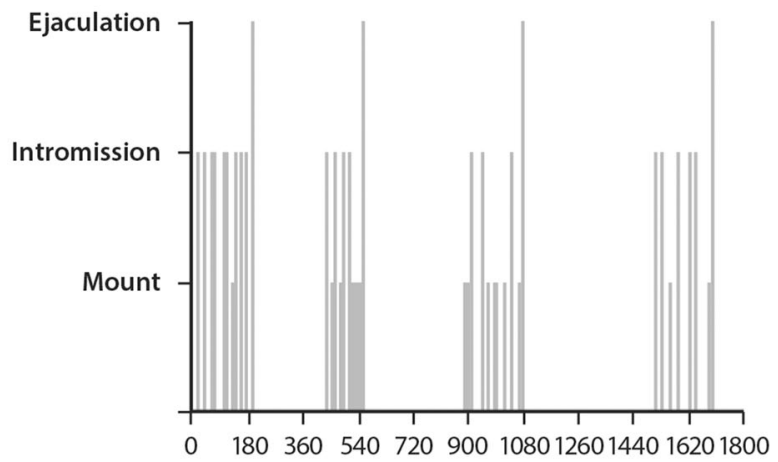

c Citalopram $(10 \mathrm{mg} / \mathrm{kg})$

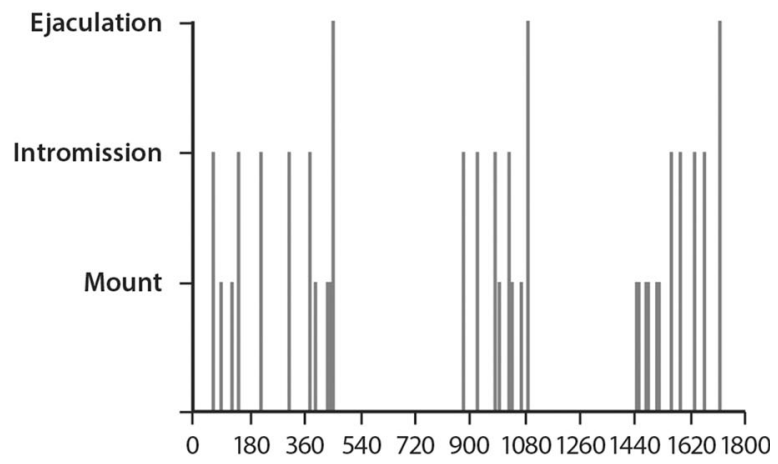

d Paroxetine $(10 \mathrm{mg} / \mathrm{kg})$

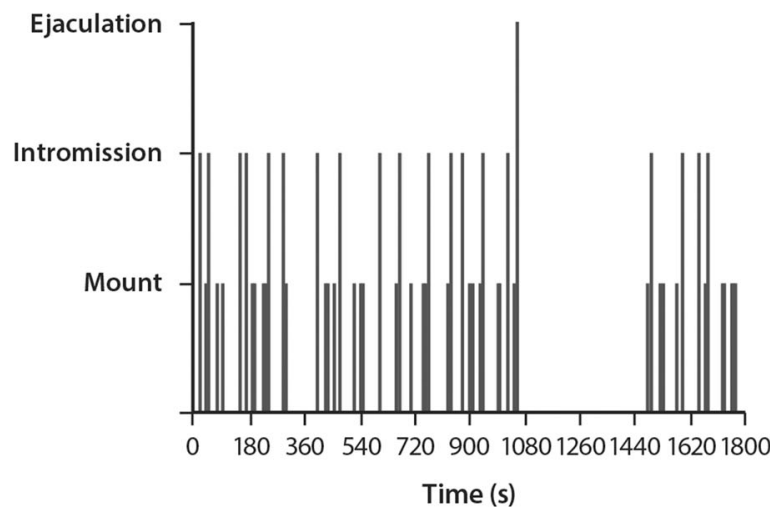

Fig. 3 Representative traces of individual sexual function after chronic (14 days) treatment. Representative traces of sexual function during the 30 -min sex test (x-axis) of individual rats ( $n=1 /$ group) treated with a vehicle, b vilazodone, c citalopram, or d paroxetine $(10 \mathrm{mg} / \mathrm{kg})$ on day 14. Y-axis shows the events scored during the test (number of mounts, intromissions, and ejaculations)

(Fig. 4a, Table 1). Notably, vilazodone showed the opposite effects of citalopram or paroxetine on 5- $\mathrm{HT}_{1 \mathrm{~A}}$ receptor levels in HIPP-CA 1 , HIPP-CA ${ }_{3}$, and EC brain regions.

\section{$5-\mathrm{HT}_{2 \mathrm{~A}}$ receptor levels}

Vilazodone-treated rats had increased $5-\mathrm{HT}_{2 \mathrm{~A}}$ receptor levels in the MPC and the DFC $(10 \mathrm{mg} / \mathrm{kg}$ only) regions $(P<.05)$ (Fig. 4b, Table 1). Similarly, paroxetine-treated rats had increased 5- $\mathrm{HT}_{2 \mathrm{~A}}$ receptor levels in the MPC and DFC regions $(P<.05)$ (Fig. 4b, Table 1). Citalopram-treated rats had increased 5- $\mathrm{HT}_{2 \mathrm{~A}}$ receptor levels in the DFC region $(P<.05)$ (Fig. 4b, Table 1).

\section{Serotonin transporter $\left(5-\mathrm{HT}_{\mathrm{T}}\right)$ levels}

Chronic treatment with vilazodone, citalopram, and paroxetine reduced $5-\mathrm{HT}_{\mathrm{T}}$ levels in all brain regions (Fig. 4c, Table 1). Compared with vehicle, chronic vilazodone-treated ( 3 and $10 \mathrm{mg} / \mathrm{kg} /$ day) rats had dose-dependent reductions of $5-\mathrm{HT}_{\mathrm{T}}$ levels in the MPC, DFC, NAc, CPu, HIPP-CA 1, HIPP-CA ${ }_{3}$, and $\mathrm{EC}$ regions $(P<.05)$. Chronic citalopram- and paroxetinetreated rats $(10 \mathrm{mg} / \mathrm{kg} /$ day for both) also had reductions in 5$\mathrm{HT}_{\mathrm{T}}$ levels compared to vehicle $(P<.05)$; the magnitude of reductions in $5-\mathrm{HT}_{\mathrm{T}}$ levels was greater for citalopram- and paroxetine-treated rats than for rats treated with both doses of vilazodone $(P<.05)$.

\section{Discussion}

The current studies compared the effects of vilazodone, a combined SSRI and 5- $\mathrm{HT}_{1 \mathrm{~A}}$ receptor partial agonist, and conventional SSRIs (citalopram and paroxetine) on male rat sexual behaviors and brain 5-HT receptor and transporter levels. SSRI treatment has been associated with dysfunction of the three sequential aspects of the sexual response cycle: sexual desire (i.e., libido), arousal (i.e., erectile function in men), and orgasm (Serretti and Chiesa 2009). Rats also exhibit a sexual response cycle, which includes introductory, copulatory, and ejaculatory phases, that is sensitive to SSRI treatment (Snoeren et al. 2014).

Vilazodone treatment had no adverse effects on copulatory and ejaculatory behaviors following acute, subchronic (7 days), and chronic (14 days) treatment; however, subchronic and chronic treatment with paroxetine, and to a lesser extent 


\section{a $5-\mathrm{HT}_{1 \mathrm{~A}}$ Receptors}

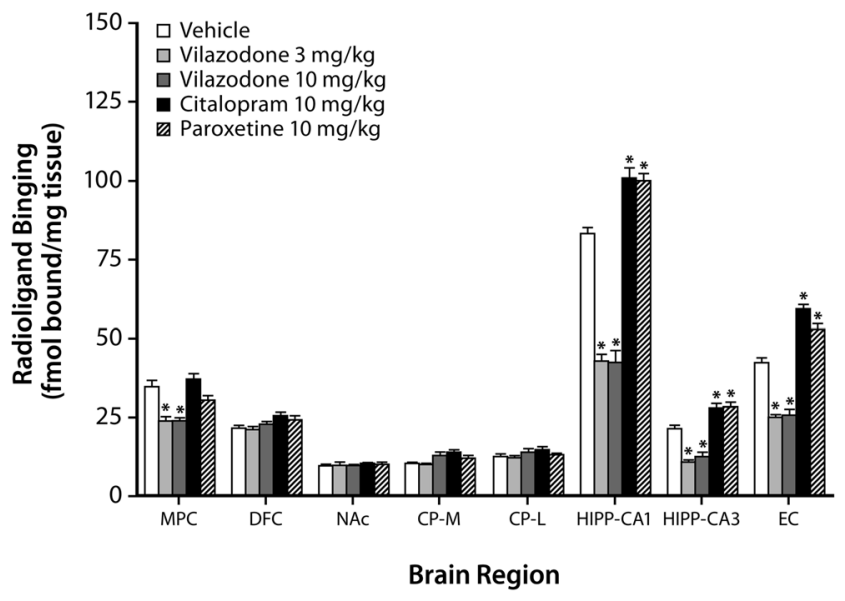

b $5-\mathrm{HT}_{2 \mathrm{~A}}$ Receptors

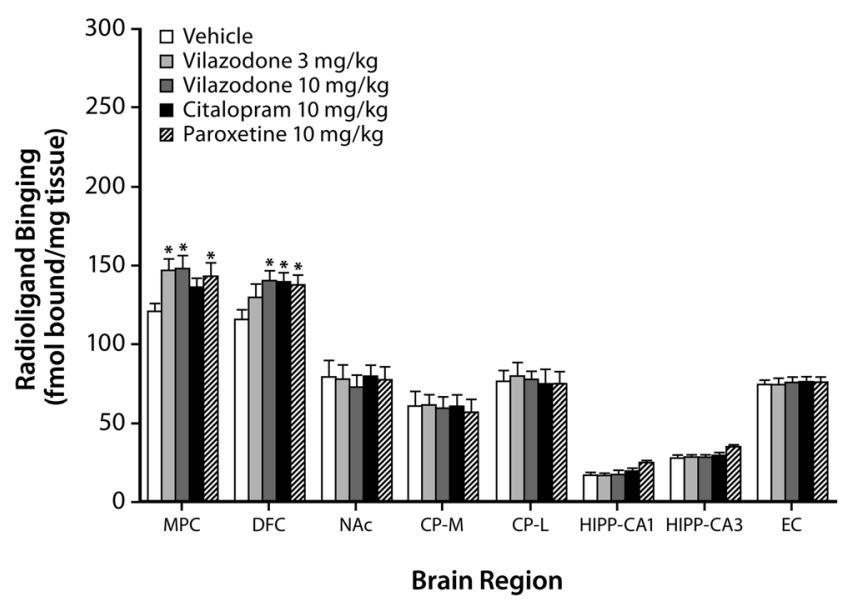

C 5-HT Transporters

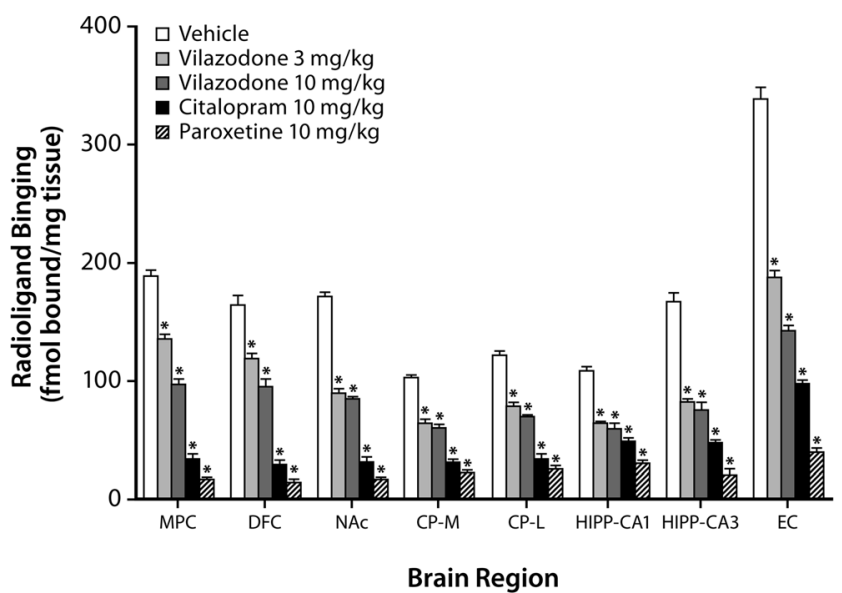

Fig. 4 Effects of chronic (14 days) vilazodone, citalopram, and paroxetine treatment on the levels of serotonergic markers in rat forebrain regions. $C P-M$ indicates caudate putamen-medial, $C P-L$ caudate putamenlateral, $D F C$ dorsal frontal cortex, $E C$ entorhinal cortex, $H I P P-C A_{l}$ hippocampus $\mathrm{CA}_{1}$ region, $\mathrm{HIPP}-\mathrm{CA}_{3}$ hippocampus $\mathrm{CA}_{3}$ region, $M P C$ medial prefrontal cortex, $N A c$ nucleus accumbens. Data are shown as the mean \pm SEM ( $n=8 /$ group). ${ }^{*} P<.05$ vs vehicle (ANOVA, post hoc Dunnett $t$ test)
Table 1 Mean percent changes from vehicle in serotonergic markers after chronic (14 days) vilazodone, citalopram, and paroxetine treatment

\begin{tabular}{|c|c|c|c|c|}
\hline \multirow[t]{2}{*}{ Brain region } & \multicolumn{2}{|c|}{ Vilazodone (\%) } & \multirow{2}{*}{$\begin{array}{l}\text { Citalopram (\%) } \\
10 \mathrm{mg} / \mathrm{kg}\end{array}$} & \multirow{2}{*}{$\begin{array}{l}\text { Paroxetine (\%) } \\
10 \mathrm{mg} / \mathrm{kg}\end{array}$} \\
\hline & $3 \mathrm{mg} / \mathrm{kg}$ & $10 \mathrm{mg} / \mathrm{kg}$ & & \\
\hline \multicolumn{5}{|l|}{$5-\mathrm{HT}_{1 \mathrm{~A}}$} \\
\hline MPC & $-31^{*}$ & $-32 *$ & NS & NS \\
\hline HIPP-CA 1 & $-49 *$ & $-49 *$ & $+21^{*}$ & $+20^{*}$ \\
\hline HIPP-CA 3 & $-49^{*}$ & $-42 *$ & $+33 *$ & $+34 *$ \\
\hline $\mathrm{EC}$ & $-42 *$ & $-42 *$ & $+39 *$ & $+24 *$ \\
\hline \multicolumn{5}{|l|}{$5-\mathrm{HT}_{2 \mathrm{~A}}$} \\
\hline MPC & $+22 *$ & $+23^{*}$ & NS & $+19^{*}$ \\
\hline $\mathrm{DFC}$ & NS & $+21^{*}$ & $+21^{*}$ & $+19 *$ \\
\hline \multicolumn{5}{|l|}{$5-\mathrm{HT}_{\mathrm{T}}$} \\
\hline MPC & $-28 *$ & $-49 *$ & $-82^{*}$ & $-91 *$ \\
\hline DFC & $-28^{*}$ & $-42 *$ & $-82 *$ & $-91 *$ \\
\hline NAc & $-48^{*}$ & $-50 *$ & $-81^{*}$ & $-90 *$ \\
\hline CP-M & $-37 *$ & $-41^{*}$ & $-69 *$ & $-78^{*}$ \\
\hline CP-L & $-36^{*}$ & $-37^{*}$ & $-72 *$ & $-79^{*}$ \\
\hline HIPP-CA 1 & $-41^{*}$ & $-45^{*}$ & $-54 *$ & $-72^{*}$ \\
\hline $\mathrm{HIPP}-\mathrm{CA}_{3}$ & $-51^{*}$ & $-55^{*}$ & $-71 *$ & $-87^{*}$ \\
\hline $\mathrm{EC}$ & $-45^{*}$ & $-58 *$ & $-71^{*}$ & $-88^{*}$ \\
\hline
\end{tabular}

$C P-M$ caudate putamen-medial, $C P-L$ caudate putamen-lateral, $D F C$ dorsal frontal cortex, $E C$ entorhinal cortex, $H I P P-C A_{1}$ hippocampus $\mathrm{CA}_{1}$ region, $\mathrm{HIPP}-\mathrm{CA}_{3}$ hippocampus $\mathrm{CA}_{3}$ region, $M P C$ medial prefrontal cortex, $N A c$ nucleus accumbens, $N S$ not significantly different from vehicle $* P<.05$ versus vehicle ( $n=8 /$ group)

citalopram, inhibited copulatory efficiency and ejaculatory parameters (decreased frequency and increased latency to first ejaculation). The paroxetine and citalopram results were consistent with previous reports in rats (de Jong et al. 2005a, b; Waldinger et al. 2002) and similar to humans (Waldinger et al. 2001). Since the 5-HT system maintains an inhibitory tone on sexual behavior, chronic elevation of extracellular 5-HT by SSRI treatment is believed to underlie delayed and inhibited ejaculation in men (Rosen et al. 1999) and male rats (Chan et al. 2010). Notably, the acute treatments had no effects on sexual behavior which, given the inhibitory role of 5-HT in sexual behaviors, may seem surprising. Acute administration of SSRIs and vilazodone results in rapid and sharp increases in extracellular 5-HT levels in the rat medial and lateral cortices (van Amsterdam and Seyfried 2014) and in the ventral hippocampus (Page et al. 2002). The increase in 5-HT levels following vilazodone treatment was nearly two times greater than following citalopram, paroxetine, or fluoxetine (van Amsterdam and Seyfried 2014). However, evidence in humans and rats suggests that acute treatments of SSRIs generally do not cause sexual dysfunction (Olivier et al. 2011; Waldinger et al. 2001, 2002); rather, SSRI-related sexual dysfunction is likely dependent upon delayed neurochemical adaptions following chronic, but not acute, elevation of 5- 
HT as well as modulations of neuroendocrine and other neurotransmitter systems (Clayton et al. 2013; Olivier et al. 2011). One notable exception may be the SSRI, dapoxetine, which has been developed for the treatment of premature ejaculation. The acute effects of dapoxetine on ejaculatory function have been attributed to its pharmacokinetic profile (i.e., rapid absorption and elimination) and its targeting of excitatory thalamic and hypothalamic regions associated with ejaculatory response (Clément et al. 2012; McMahon 2011). However, although one preclinical study found high-dose dapoxetine to have limited effects on ejaculation latency in rapidejaculating rats, other studies in normal male rats did not show differences between dapoxetine and paroxetine (Olivier 2015). From this standpoint, dapoxetine does not appear to differ from other SSRIs in its pharmacologic ability to inhibit ejaculation latency in either rats or men (Olivier 2015). In contrast to vilazodone, acute administration of 5- $\mathrm{HT}_{1 \mathrm{~A}}$ receptor agonists stimulates copulatory and ejaculatory behaviors in male rats (Arnone et al. 1995; de Jong et al. 2005b; Snoeren et al. 2014), which may be due to the differences between full and partial agonism at the 5- $\mathrm{HT}_{1 \mathrm{~A}}$ receptor; other differences in acute neurophysiological and behavioral responses in rats have been reported between full $5-\mathrm{HT}_{1 \mathrm{~A}}$ receptor agonists and vilazodone (Bartoszyk et al. 1997; Page et al. 2002).

Since the impetus for this study was to better understand the adverse effects of SSRIs and other antidepressants on sexual functioning in patients who require such treatments, the current study focused on brain regions in the limbic system known to be associated with MDD and SSRI-mediated sexual dysfunction (Baldessarini 2006; Snoeren et al. 2014). However, it is important to note that other structures rich in 5-HT receptors, such as the raphé magnus, raphé pallidus, and gigantocelluar nuclei of the ventral medulla, may also contribute to the effects of antidepressants on male sexual behavior. Studies in rats have reported various effects of SSRIs on 5-HT receptor density. For example, repeated citalopram exposure was found to increase $5-\mathrm{HT}_{1 \mathrm{~A}}$ receptors and decrease $5-\mathrm{HT}_{2 \mathrm{~A}}$ receptors in the hippocampus in one study (Klimek et al. 1994), while a later study using positron emission tomography along with autoradiographic assays found no effect of chronic citalopram on $5-\mathrm{HT}_{1 \mathrm{~A}}$ receptor density in the dorsal raphé nucleus, frontal cortex, or hippocampus (Moulin-Sallanon et al. 2009). Repeated administration with paroxetine in rats was shown to have no effect on the density of $5-\mathrm{HT}_{1 \mathrm{~A}}$ receptors in the hypothalamus ( $\mathrm{Li}$ et al. 1997). In the current study, chronic vilazodone treatment reduced postsynaptic $5-\mathrm{HT}_{1 \mathrm{~A}}$ receptor levels in the cortical and hippocampal regions, while citalopram and paroxetine increased $5-\mathrm{HT}_{1 \mathrm{~A}}$ receptor levels in the same brain regions. Importantly, the differential effects of the drugs on postsynaptic 5-HT $1 \mathrm{~A}$ receptor levels occurred in the limbic cortex (MPC and EC) and the hippocampus. These are key brain substrates that receive afferent 5 -HT projections from the dorsal and median raphé nucleus and are involved in the regulation of ejaculation (Snoeren et al. 2014). Stimulation of postsynaptic $5-\mathrm{HT}_{1 \mathrm{~A}}$ receptors by vilazodone via both direct activation and elevated extracellular 5-HT levels in the prefrontal cortex and hippocampus (Hughes et al. 2005; Page et al. 2002) may lead to 5-HT $1 \mathrm{~A}$ receptor downregulation.

The results of $5-\mathrm{HT}_{1 \mathrm{~A}}$ receptor downregulation and lack of sexual side effects with vilazodone may complement a recent electrophysiology study by Ashby et al. This study reported that presynaptic $5-\mathrm{HT}_{1 \mathrm{~A}}$ autoreceptors in the dorsal raphé nuclei, which normally inhibit 5-HT neuron firing, showed much greater desensitization following chronic vilazodone treatment than following a similar treatment with fluoxetine (Ashby et al. 2013). Therefore, this desensitization would be expected to increase extracellular 5-HT release in afferent brain regions, including the cortex and hippocampus, and consequently result in a higher likelihood of sexual side effects following chronic vilazodone administration compared with conventional SSRIs. However, one possible explanation for the lack of sexual side effects of vilazodone is that the $5-\mathrm{HT}_{1 \mathrm{~A}}$ partial agonist activity of this molecule may stimulate the postsynaptic $5-\mathrm{HT}_{1 \mathrm{~A}}$ receptors which can counteract the inhibitory effects of elevated extracellular 5-HT resulting from presynaptic $5-\mathrm{HT}_{1 \mathrm{~A}}$ receptor desensitization and $5-\mathrm{HT}_{\mathrm{T}}$ blockade. In accordance with this explanation, systemic administration of several other $5-\mathrm{HT}_{1 \mathrm{~A}}$ receptor agonists and partial agonists enhanced ejaculatory behaviors in male rodents (Arnone et al. 1995; de Jong et al. 2005b; Snoeren et al. 2014). For instance, de Jong et al. (2005b) reported that a challenge with the full $5-\mathrm{HT}_{1 \mathrm{~A}}$ receptor agonist 8-OH-DPAT in male rats chronically treated with paroxetine restored the sexual behavior of these animals. Vilazodone has demonstrated comparable activity to 8-OH-DPAT at postsynaptic $5-\mathrm{HT}_{1 \mathrm{~A}}$ receptors in hippocampal tissue (Hughes et al. 2005). If this hypothesis is correct, the timing of the sexual behavior tests in rats relative to drug administration may be critical and will be investigated in a future study. In humans, however, this may be less of an issue because of the much longer half-life of vilazodone.

Chronic treatment with vilazodone, citalopram, and paroxetine reduced $5-\mathrm{HT}_{\mathrm{T}}$ levels in all of the tested forebrain regions. This is consistent with existing literature demonstrating that elevated extracellular 5-HT concentrations in vitro (Jorgensen et al. 2014) and chronic SSRI and serotonin norepinephrine reuptake inhibitor (SNRI) treatment in vivo (Mirza et al. 2007) can lead to reduced 5- $\mathrm{HT}_{\mathrm{T}}$ expression. A consequence of reduced 5- $\mathrm{HT}_{\mathrm{T}}$ availability is enhanced postsynaptic serotonergic neurotransmission, which may in turn contribute to sexual dysfunction (Chan et al. 2011). In the current study, the magnitude of reductions in $5-\mathrm{HT}_{\mathrm{T}}$ levels was greater for citalopram and paroxetine (maximum reductions of 80 and $91 \%$, respectively) than for vilazodone (maximum reduction of $58 \%$ ). Because of the differential effects of vilazodone relative to the SSRIs on both $5-\mathrm{HT}_{\mathrm{T}}$ and $5-\mathrm{HT}_{1 \mathrm{~A}}$ 
receptors, it is likely that the dynamics of extracellular 5-HT differ between rats that are chronically treated with the two different types of antidepressants.

The increases in cortical 5- $\mathrm{HT}_{2 \mathrm{~A}}$ receptor levels following the different types of antidepressant treatments may suggest a common mechanism of action that mediates the beneficial therapeutic effects of dissimilar antidepressant drugs. The 5- $\mathrm{HT}_{2 \mathrm{~A}}$ receptor is purported to have an inhibitory role in copulatory behavior, as shown by a decreased number of rats that initiated copulation after receiving $5-\mathrm{HT}_{2 \mathrm{~A}}$ receptor agonists in a sexual behavior test (Olivier et al. 2011). During the day 14 sexual behavior tests, the majority of citalopram- and paroxetinetreated rats had $\leq 2$ ejaculations and several rats had no ejaculations. These results may be related to elevated $5-\mathrm{HT}_{2 \mathrm{~A}}$ receptor activity following increased expression in cortical areas.

\section{Conclusion}

SSRI treatment is associated with direct negative effects on sexual function that may lead to treatment discontinuation and reduced quality of life (Hu et al. 2004). Combination therapy with SSRIs and 5- $\mathrm{HT}_{1 \mathrm{~A}}$ agonists and partial agonists, such as buspirone, has been shown to ameliorate SSRI-induced sexual dysfunction (Clayton and Montejo 2006; Landen et al. 1999). In the current preclinical studies, unlike the conventional SSRIs, vilazodone was not associated with diminished copulatory or ejaculatory behaviors in male rats. These results support clinical trial data showing that vilazodone treatment, while effective in improving depressive symptoms, was associated with a relatively low incidence of direct adverse effects on sexual function (Clayton et al. 2013, 2015). The distinct effects of vilazodone on the $5-\mathrm{HT}_{\mathrm{T}}$ and $5-\mathrm{HT}_{1 \mathrm{~A}}$ receptors may enhance serotonergic transmission to achieve clinical efficacy in depression while limiting the adverse events of SSRIinduced sexual dysfunction.

Acknowledgments Writing and editorial support for the preparation of the manuscript was provided by Jonathan Kelley, Ph.D. and Adam Ruth, Ph.D., both formerly of Prescott Medical Communications Group, Chicago, Illinois, a contractor of Forest Research Institute, an Allergan affiliate.

Compliance with ethical standards All behavioral experiments, including the drug administrations, were reviewed and approved by Utrecht University's animal welfare committee (DEC).

Funding Support for this publication was funded by Forest Laboratories, LLC, an Allergan affiliate, Jersey City, NJ, USA. F.I. Tarazi has received grant support from Forest Laboratories, LLC, an Allergan affiliate.

Conflict of interest Lundbeck and Shire Pharmaceuticals, R.S. Oosting, J.S.W. Chan, and B. Olivier have no conflicts of interest to disclose. P. Banerjee is an employee of Forest Research Institute, an Allergan affiliate. Y.K. Choi has no conflicts of interest to disclose.
Open Access This article is distributed under the terms of the Creative Commons Attribution 4.0 International License (http:// creativecommons.org/licenses/by/4.0/), which permits unrestricted use, distribution, and reproduction in any medium, provided you give appropriate credit to the original author(s) and the source, provide a link to the Creative Commons license, and indicate if changes were made.

\section{References}

Arnone M, Baroni M, Gai J, Guzzi U, Desclaux MF, Keane PE, Le Fur G, Soubrie P (1995) Effect of SR 59026A, a new 5-HT(1A) receptor agonist, on sexual activity in male rats. Behav Pharmacol 6:276-282

Ashby CR Jr, Kehne JH, Bartoszyk GD, Renda MJ, Athanasiou M, Pierz KA, Seyfried CA (2013) Electrophysiological evidence for rapid 5HT(1)A autoreceptor inhibition by vilazodone, a 5-HT(1)A receptor partial agonist and 5-HT reuptake inhibitor. Eur J Pharmacol 714: 359-365

Ashton AK, Jamerson BD, Weinstein LW, Wagoner C (2005) Antidepressant-related adverse effects impacting treatment compliance: results of a patient survey. Curr Ther Res Clin Exp 66:96-106

Baldessarini RJ (2006) Drug therapy of depression and anxiety disorders. In: Brunton LL, Lazo JS, Parker KL (eds) Goodman and Gilman's the pharmacological basis of therapeutics. McGraw-Hill, New York, pp 429-460

Bartoszyk GD, Hegenbart R, Ziegler H (1997) EMD 68843, a serotonin reuptake inhibitor with selective presynaptic 5-HT $1 \mathrm{~A}$ receptor agonistic properties. Eur J Pharmacol 322:147-153

Blier P, Ward NM (2003) Is there a role for 5-HT1A agonists in the treatment of depression? Biol Psychiatry 53:193-203

Chan JS, Waldinger MD, Olivier B, Oosting RS (2010) Drug-induced sexual dysfunction in rats. Curr Protoc Neurosci 53 (Suppl):9.34.19.34.11

Chan JS, Snoeren EM, Cuppen E, Waldinger MD, Olivier B, Oosting RS (2011) The serotonin transporter plays an important role in male sexual behavior: a study in serotonin transporter knockout rats. J Sex Med 8:97-108

Clayton AH, Montejo AL (2006) Major depressive disorder, antidepressants, and sexual dysfunction. J Clin Psychiatry 67(Suppl 6):33-37

Clayton AH, Kennedy SH, Edwards JB, Gallipoli S, Reed CR (2013) The effect of vilazodone on sexual function during the treatment of major depressive disorder. J Sex Med 10:2465-2476

Clayton AH, Gommoll C, Chen D, Nunez R, Mathews M (2015) Sexual dysfunction during treatment of major depressive disorder with vilazodone, citalopram, or placebo: results from a phase IV clinical trial. Int Clin Psychopharmacol 30:216-223

Clément P, Laurin M, Compagnie S, Facchinetti P, Bernabé J, Alexandre L, Giuliano F (2012) Effect of dapoxetine on ejaculatory performance and related brain neuronal activity in rapid ejaculator rats. $\mathrm{J}$ Sex Med 9:2562-2573

Dawson LA, Watson JM (2009) Vilazodone: a 5-HT1A receptor agonist/ serotonin transporter inhibitor for the treatment of affective disorders. CNS Neurosci Ther 15:107-117

de Jong TR, Pattij T, Veening JG, Dederen PJ, Waldinger MD, Cools AR, Olivier B (2005a) Citalopram combined with WAY 100635 inhibits ejaculation and ejaculation-related Fos immunoreactivity. Eur J Pharmacol 509:49-59

de Jong TR, Pattij T, Veening JG, Waldinger MD, Cools AR, Olivier B (2005b) Effects of chronic selective serotonin reuptake inhibitors on 8-OH-DPAT-induced facilitation of ejaculation in rats: comparison of fluvoxamine and paroxetine. Psychopharmacology 179:509-515

Forest Pharmaceuticals (2011) Viibryd [prescribing information]. Forest Pharmaceuticals, LLC, St. Louis 
Hu XH, Bull SA, Hunkeler EM, Ming E, Lee JY, Fireman B, Markson LE (2004) Incidence and duration of side effects and those rated as bothersome with selective serotonin reuptake inhibitor treatment for depression: patient report versus physician estimate. J Clin Psychiatry 65:959-965

Hughes ZA, Starr KR, Langmead CJ, Hill M, Bartoszyk GD, Hagan JJ, Middlemiss DN, Dawson LA (2005) Neurochemical evaluation of the novel 5-HT 1A receptor partial agonist/serotonin reuptake inhibitor, vilazodone. Eur J Pharmacol 510:49-57

Jorgensen TN, Christensen PM, Gether U (2014) Serotonin-induced down-regulation of cell surface serotonin transporter. Neurochem Int 73:107-112

Kennedy SH, Rizvi S (2009) Sexual dysfunction, depression, and the impact of antidepressants. J Clin Psychopharmacol 29:157-164

Kessler RC, Birnbaum H, Bromet E, Hwang I, Sampson N, Shahly V (2010) Age differences in major depression: results from the National Comorbidity Survey Replication (NCS-R). Psychol Med 40:225-237

Khan A, Cutler AJ, Kajdasz DK, Gallipoli S, Athanasiou M, Robinson DS, Whalen H, Reed CR (2011) A randomized, double-blind, placebo-controlled, 8-week study of vilazodone, a serotonergic agent for the treatment of major depressive disorder. J Clin Psychiatry 72: $441-447$

Klimek V, Zak-Knapik J, Mackowiak M (1994) Effects of repeated treatment with fluoxetine and citalopram, 5-HT uptake inhibitors, on 5HT1A and 5-HT2 receptors in the rat brain. J Psychiatry Neurosci 19:63-67

Landen M, Eriksson E, Agren H, Fahlen T (1999) Effect of buspirone on sexual dysfunction in depressed patients treated with selective serotonin reuptake inhibitors. J Clin Psychopharmacol 19:268-271

Li Q, Muma N, Battaglia G, Van de Kar L (1997) A desensitization of hypothalamic 5-HT1A receptors by repeated injections of paroxetine: reduction in the levels of $\mathrm{G}(\mathrm{i})$ and $\mathrm{G}(\mathrm{o})$ proteins and neuroendocrine responses, but not in the density of 5-HT1A receptors. J Pharmacol Exp Ther 282:1581-1590

Looney C, Thor KB, Ricca D, Marson L (2005) Differential effects of simultaneous or sequential administration of paroxetine and WAY100,635 on ejaculatory behavior. Pharmacol Biochem Behav 82: $427-433$

McMahon CG (2011) Efficacy of dapoxetine in the treatment of premature ejaculation. Clin Med Insights Reprod Health 5:25-39

Mirza NR, Nielsen EO, Troelsen KB (2007) Serotonin transporter density and anxiolytic-like effects of antidepressants in mice. Prog Neuropsychopharmacol Biol Psychiatry 31:858-866

Moulin-Sallanon M, Charnay Y, Ginovart N, Perret P, Lanfumey L, Hamon M, Hen R, Fagret D, Ibáñez V, Millet P (2009) Acute and chronic effects of citalopram on 5-HT1A receptor-labeling by $[18 \mathrm{~F}] \mathrm{MPPF}$ and -coupling to receptors-G proteins. Synapse 63: $106-116$

Nantz E, Liu-Seifert H, Skljarevski V (2009) Predictors of premature discontinuation of treatment in multiple disease states. Patient Prefer Adherence 3:31-43

Olivier B (2015) Serotonin: a never-ending story. Eur J Pharmacol 753:218
Olivier B, Chan JS, Snoeren EM, Olivier JD, Veening JG, Vinkers CH, Waldinger MD, Oosting RS (2011) Differences in sexual behaviour in male and female rodents: role of serotonin. Curr Top Behav Neurosci 8:15-36

Page ME, Cryan JF, Sullivan A, Dalvi A, Saucy B, Manning DR, Lucki I (2002) Behavioral and neurochemical effects of 5-\{4-[4-(5-cyano-3indolyl)-butyl)-butyl]-1-piperazinyl $\}$-benzofuran-2-carboxamide (EMD 68843): a combined selective inhibitor of serotonin reuptake and 5-hydroxytryptamine1A receptor partial agonist. J Pharmacol Exp Ther 302:1220-1227

Pattij T, de Jong TR, Uitterdijk A, Waldinger MD, Veening JG, Cools AR, van der Graaf PH, Olivier B (2005) Individual differences in male rat ejaculatory behaviour: searching for models to study ejaculation disorders. Eur J Neurosci 22:724-734

Rickels K, Athanasiou M, Robinson DS, Gibertini M, Whalen H, Reed CR (2009) Evidence for efficacy and tolerability of vilazodone in the treatment of major depressive disorder: a randomized, double-blind, placebo-controlled trial. J Clin Psychiatry 70:326-333

Rizvi SJ, Kennedy SH (2013) Management strategies for SSRI-induced sexual dysfunction. J Psychiatry Neurosci 38:E27-E28

Robinson DS, Kajdasz DK, Gallipoli S, Whalen H, Wamil A, Reed CR (2011) A 1-year, open-label study assessing the safety and tolerability of vilazodone in patients with major depressive disorder. J Clin Psychopharmacol 31:643-646

Rosen RC, Lane RM, Menza M (1999) Effects of SSRIs on sexual function: a critical review. J Clin Psychopharmacol 19:67-85

Serretti A, Chiesa A (2009) Treatment-emergent sexual dysfunction related to antidepressants: a meta-analysis. J Clin Psychopharmacol 29:259-266

Snoeren EM, Veening JG, Olivier B, Oosting RS (2014) Serotonin 1A receptors and sexual behavior in male rats: a review. Pharmacol Biochem Behav 121:102-114

Tarazi FI, Zhang K, Baldessarini RJ (2002) Long-term effects of olanzapine, risperidone, and quetiapine on serotonin $1 \mathrm{~A}, 2 \mathrm{~A}$ and $2 \mathrm{C}$ receptors in rat forebrain regions. Psychopharmacology (Berlin) 161:263-270

van Amsterdam C, Seyfried CA (2014) Mechanism of action of the bimodal antidepressant vilazodone: evidence for serotonin1Areceptor-mediated auto-augmentation of extracellular serotonin output. Psychopharmacology 231:2547-2558

Waldinger MD, Zwinderman AH, Olivier B (2001) SSRIs and ejaculation: a double-blind, randomized, fixed-dose study with paroxetine and citalopram. J Clin Psychopharmacol 21:556-560

Waldinger MD, van De Plas A, Pattij T, van Oorschot R, Coolen LM, Veening JG, Olivier B (2002) The selective serotonin re-uptake inhibitors fluvoxamine and paroxetine differ in sexual inhibitory effects after chronic treatment. Psychopharmacology (Berlin) 160: 283-289

Zhang K, Davids E, Tarazi FI, Baldessarini RJ (2002) Serotonin transporter binding increases in caudate-putamen and nucleus accumbens after neonatal 6-hydroxydopamine lesions in rats: implications for motor hyperactivity. Brain Res Dev Brain Res 137:135-138 